\title{
STUDI TENTANG KEAMANAN DAN KESELAMATAN PENGUNJUNG HUBUNGANNYA DENGAN CITRA DESTINASI (STUDI KASUS GEMBIRA LOKA ZOO)
}

\author{
Suharto \\ Dosen Akademi Pariwisata "STIPARY" Yogyakarta \\ email : hartamas1970@gmail.com
}

\begin{abstract}
Image is one of the essential elements for a tourist destination and a description about the impression of a tourist destination. A good image will motivate tourist to visit a destination. The research uses Gembira Loka Zoo as an object. The purpose from this research was to identify the factors related with the image of a destination, especially in the management of the security and safety of visitors conducted by travel managers Gembira Loka Zoo.

The method use in this research related to the security and safety of visitors is descriptive Research is Descriptive to investigate population and samples. Population is tourists who visit Gembira Loka Zoo and the samples are 100 respondents. In addition researchers also conduct observation, Questionnaires and documentation in the data collection. The analysis technique used there are several steps that incude the instrument of accession test, validity, reliability, hypothesis, coefficient of determination and F test and $T$.

The result showed a Gembira Loka Zoo has a good image of tourist mind and the result showed significant correlation between Gembira Loka Zoo Image and tourist visiting motivation. With this reserach is expected that manager can improve all of the aspect of Gembira Loka Zoo so it can be motivate tourist to visit.
\end{abstract}

Keywords : Gembira Loka Zoo Image, Visitor Safety and Security

\section{PENDAHULUAN}

Upaya peningkatan pengunjung dalam sebuah destinasi wisata perlu dilakukan melalui peningkatan pengelolaan agar para pengunjung merasa nyaman, aman dan terjamin kesehatannya. Terlebih pada sektor pariwisata yang menyelenggarakan berbagai atraksi yang berkaitan dengan keselamatan pengunjung. Secara umum pengelolaan (manajemen) diartikan sebagai suatu langkah-langkah yang sistematis yang mencakup planning (perencanaan), directing (mengarahkan), organizing (mengorganisasi dan mengkoordinasi) dan controlling (pengawasan).
Definisi pengelolaan (manajemen) menurut Leiper dalam I Gde Pitana (2009: 80) merujuk kepada seperangkat peranan yang dilakukan oleh seseorang atau sekelompok orang atau bisa juga merujuk kepada fungsi-fungsi yang melekat pada peran tersebut.

Upaya menjamin keamanan dan keselamatan pariwisata khususnya para wisatawan merupakan bagian dari tuntutan masyarakat agar sebuah destinasi wisata dapat terus menarik wisatawan. Sehubungan dengan hal tersebut pada tahun 1991 WTO telah merekomendasikan upaya-upaya yang perlu diambil untuk keamanan pariwisata yaitu bahwa "tiap-tiap 
Negara hendaknya mengembangkan suatu kebijakan nasional bidang keselamatan pariwisata yang diselaraskan dengan upaya pencegahan resiko-resiko bagi wisatawan" (Frans Gromang, 2002: 12).

Berbagai kemungkinan yang akan muncul sebagai resiko keberadaan wisatawan ketika berada di destinasi wisata dapat dikelompokkan menjadi beberapa hal antara lain:

1. Lingkungan hidup manusia dan lembaga non pariwisata, seperti kejahatan karena pencurian, pencopetan, penganiayaan, penodongan, dan penculikan

2. Sektor pariwisata dan sektor usaha jasa, seperti: terbatasnya standar keselamatan pada gedung, fasilitas umum, fasilitas wisata, sanitasi lingkungan dari berbagai hal yang menimbulkan risiko bagi wisatawan, seperti: bahaya kebakaran, binatang buas, kecelakaan darat maupun air, dan sebagainya.

3. Risiko terhadap alam dan lingkungan seperti risiko karena flora dan fauna.

Menyadari pentingnya faktor keamanan dan keselamatan wisatawan maka muncul gagasan World Tourism Organization (WTO) untuk memberikan tuntunan sebagai acuan bagi pengambil kebijakan di berbagai industri pariwisata (Frans Gromang, 2002: 2). Keamanan dan keselamatan pengunjung bukan saja semata menjadi tanggung jawab pemilik (owner) atau pengelola destinasi wisata tetapi juga bagian dari tanggung jawab Pemerintah Daerah maupun pusat (stakeholder) dalam memajukan pariwisata di tingkat daerah. Keamanan dan keselamatan pengunjung diprediksikan akan memberikan kontribusi pada peningkatan pengunjung selanjutnya dan akan merupakan faktor pendorong terciptanya tanggung jawab sosial kepada masyarakat (company sosial responsibility atau CSR).

Berkaitan dengan pentingnya sebuah keamanan dan keselamatan pengunjung pada sebuah kawasan atau destinasi wisata, maka perlu dilakukan sebuah penelitian. Oleh karena itu penelitian ini akan dilakukan di kawasan wisata Kebun Binatang Gembira Loka (Gembira Loka Zoo), melalui judul "Analisis Pengelolaan Keamanan dan Keselamatan Pengunjung Terhadap Citra Destinasi Wisata". Gembira Loka Zoo dijadikan studi kasus penelitian ini karena destinasi wisata ini diperkirakan banyak resiko keselamatan dan keamanan pengunjung baik terhadap lingkungan fisiknya (lingkungan alam) maupun lingkungan non fisik seperti keberadaan satwa sebagai point of interest utamanya. Pengelolaan keamanan dan keselamatan pengunjung di tempat wisata sangat berperan dalam memberikan rasa nyaman dan aman bagi wisatawan untuk berkunjung yang pada gilirannya akan berdampak pada citra suatu destinasi. Pengelolaan keamanan dan keselamatan dalam suatu tempat wisata akan dapat menciptakan rasa aman, nyaman, terlindungi sehingga dengan keamanan dan keselamatan tersebut maka akan tercipta citra positif dari suatu destinasi. Berdasarkan uraian tersebut maka rumusan masalah dalam penelitian ini adalah: "Apakah ada pengaruh yang signifikan aspek pengelolaan keamanan dan keselamatan para pengunjung terhadap citra destinasi di Gembira Loka zoo?"

Citra sebuah destinasi wisata berhubungan dengan banyak faktor, seperti: faktor pelayanan yang diberikan oleh perusahaan, faktor lokasi, fasilitas, tanggung jawab perusahaan atas keamanan dan keselamatan pengunjung, faktor lingkungan 
alam, tangggung jawab perusahaan terhadap berbagai resiko yang ditimbulkan atas atraksi yang disediakan, dan lain-lain. Beragamnya faktor yang berhubungan dengan citra suatu destinasi, maka tujuan dalam penelitian ini penulis membatasi pada persoalan pengelolaan keamanan dan keselamatan pengunjung yang dilakukan oleh pengelola destinasi wisata, khususnya di Gembira Loka zoo.

Hasil penelitian ini diharapkan bermanfaat bagi pihak-pihak yang terkait :

1. Bagi Objek Wisata Gembira Loka zoo. Merupakan salah satu bentuk acuan untuk pengembangan pariwisata bahwa pengelolaan keamanan dan keselamatan pengunjung harus dipenuhi sebagai syarat mutlak yang harus diperhitungkan dalam perencanaan pariwisata agar wisatawan merasakan keamanan dan kenyaman dalam menikmati wisata. Bagi pengelola dapat meningkatkan citra positif di lokasi wisata sehingga dapat meningkatkan jumlah pengunjung. Bagi penyedia jasa dapat memberikan keuntungan yang sangat besar guna mengangkat perekonomian masyarakat yang terlibat langsung di kawasan wisata.

2. Bagi Lembaga Pendidikan Tinggi Pariwisata dan Industri Pariwisata pada umumnya. Bagi lembaga pendidikan pariwisata baik pada program studi perhotelan maupun program studi pariwisata, penelitian ini dapat melahirkan tenaga ahli dalam bidang industri pariwisata yang profesional. Hasil penelitian ini dapat dijadikan acuan untuk penelitian selanjutnya bagi mahasiswa, khususnya jurusan yang berkaitan dengan industri pariwisata maupun akomodasi perhotelan.
3. Bagi peneliti.. Mendapatkan pengtahuan tentang berbagai faktor yang berkaitan dengan pengelolaan keselamatan dan keamanan pengunjung di sektor pariwisata.

\section{LITERATUR REVIEW}

\section{Pegertian dan Unsur Citra Destinasi}

Menurut Philip Kotler, citra adalah seperangkat keyakinan, ide, dan kesan yang dimiliki seseorang terhadap suatu obyek (Kotler, 1997: 259). Sutisna mengemukakan "Citra adalah total persepsi terhadap suatu obyek yang dibentuk dengan memproses informasi dan berbagai sumber setiap waktu (Sutisna, 2001: 83). Menurut Alma (2002: 317), “citra sebagai kesan yang diperoleh dengan pengetahuan dan pengalaman seseorang tentang sesuatu". Rhenald Kasali mendefinisikan citra sebagai kesan timbul karena pemahaman akan suatu kenyataan (2003:28). Berdasarkan pendapat-pendapat tersebut, citra menunjukkan kesan suatu obyek terhadap obyek lain yang terbentuk dengan memproses informasi setiap waktu dari berbagai sumber terpercaya. Destinasi memiliki arti sebagai tempat tujuan; tempat tujuan pengiriman (http://kbbi.web.id/ destinasi), sehingga destinasi wisata diartikan sebagai tempat tujuan wisata.

Sebuah citra merupakan sesuatu yang abstrak (intangibility) yang tidak bisa dicicipi, dilihat, didengar, dibaui, maupun dirasakan maka perusahaan penyelenggara jasa harus benar-benar dapat meyakinan kepada calon wisatawan dan memberikan bukti nyata terhadap wisatawan ketika berada di destinasi wisata. Salah satunya dengan memberikan pelayanan yang prima kepada wisatawan berupa jaminan terhadap keamanan dan keselamatan para wisatawan tersebut. 
Upaya mempertahankan dan mengembangkan destinasi terkait dengan berbagai unsur yang dapat dijabarkan sebagai berikut.

1. Atraksi wisata, atraksi yang dimaksud yaitu elemen-elemen yang terkandung dalam destinasi dan lingkungan secara individual atau kombinasinya, memiliki peranan penting dalam memotivasi pengunjung/wisatawan untuk berkunjung ke destinasi tersebut. Termasuk dalam atraksi wisata seperti landscape, pantai pegunungan, iklim, lembah ataupun atraksi buatan seperti kota bersejarah, tanaman dan resort, atraksi budaya seperti atraksi teatrikal, drama festival, museum dan galeri, dan atraksi sosial seperti kesempatan berbaur dengan masyarakat di daerah tujuan wisata dan ikut mengalami cara hidup bersama mereka

2. Fasilitas destinasi, yanag dimaksud yaitu elemen dalam suatu destinasi yang memungkinkan wisatawan tinggal di destinasi tersebut untuk menikmati atau berpartisipasi dalam atraksi yang ditawarkan. Fasilitas dimaksud dapat mencakup: akomodasi, restoran, café dan bar, transportasi termasuk penyewaan alat transportasi dan taksi, serta pelayanan lain termasuk toko salon pelayanan informasi dan sebagainya.

3. Aksesibilitas, yaitu mudah atau sulitnya wisatawan menjangkau destinasi yang diinginkannya. Hal ini berkaitan dengan infrastruktur transportasi dan teknologi trasportasi yang mampu menghemat waktu dan biaya untuk menjangkau destinasi wisata tersebut.

4. Imej, yaitu merupakan kepercayaan yang dimiliki wisatawan tentang produk atau pelayanan yang mereka beli atau akan beli. Imej destinasi tidak selalu berdasarkan pengalaman atau fakta atau dapat dibentuk sedemikian rupa sehingga menjadi faktor motivasi atau pendorong yang kuat untuk melakukan perjalanan wisata ke destinasi tersebut.

5. Harga, yaitu merupakan jumlah keseluruhan dari biaya-biaya selama perjalanan wisata yang mencakup akomodasi, makanan dan minuman, biaya perjalan, dan partisipasi dalam pelayanan yang dikonsumsi selama berada destinasi yang dituju (Gromang, 2002: 24).

6. Uraian di atas menunjukkan bahwa upaya peningkatan kualitas citra destinasi dapat dipengaruhi oleh berbagai faktor salah satunya yaitu menjaga imej destinasi itu sendiri. Menjaga imej destinasi dalam menegakkan citra suatu destinasi dapat dilakukan dengan pendayagunaan sumber daya manusia dalam menjaga keamanan dan keselamatan para pengunjung atau wisatawan, sehingga mereka merasa dilindungi selama berada di destinasi wisata.

\section{Manajemen Keamanan dan Keselamatan Pengunjung di Tempat Wisata}

\section{a. Pengertian manajemen}

Pengertian manajemen menurut Robbin dan Coulter (2007:8) (dalam Subekhi dan Jauhar, 2012:17), "Manajemen yaitu proses pengkoordinasian kegiatankegiatan pekerjaan, sehingga pe-kerjaan tersebut terealisasikan secara efisien dan efektif dengan dan melalui orang lain. Efisien berarti memperoleh output terbesar dengan input terkecil, digambarkan sebagai 'melakukan segala sesuatu secara benar'. 
Efektif yakni menyelesaikan kegiatankegiatan sasaran organisasi dapat dicapai, digambarkan sebagai 'melakukan segala sesuatu dengan benar'.

Menurut Hasibuan (2014: 9), "manajemen sebagai ilmu dan seni mengatur proses pemanfaatan sumber daya manusia dan sumber-sumber daya lainnya secara efektif dan efisien untuk mencapai suatu tujuan tertentu". Perbedaan karakter wisata akan membedakan potensi risiko antara satu tempat dengan tempat lain sehingga menuntut pengelola wisata dapat melakukan estimasi risiko secara mendalam. Estimasi ini akan menghitung derajat risiko yang terbagai dalam tiga level yaitu tinggi, menengah dan rendah (Siahaan, 2007:34-35). Dalam UndangUndang Nomor 10 Tahun 2009 tentang Kepariwisataan pasal 26 (d), Keamanan dan Keselamatan wisatawan harus diperhatikan oleh pihak pengusaha pariwisata atau pengelola wisata.

Menurut Robertson et al. (2006), Rencana Keamanan dan Keselamatan Pariwisata Nasional, pariwisata sangat kritis, artinya terhadap ekonomi nasional, pembangunannya, serta manajemennya adalah prioritas dan pembangunan tentang Keamanan Pariwisata Nasional direkomendasikan sebagai alat ukur untuk mencapainya. Rencana tersebut mengikutsertakan isu di area utama sebagai berikut.

a. Potensi resiko terhadap pariwisata;

b. Deteksi dan pencegahan atas pelanggaran terhadap para pengunjung;

c. Proteksi terhadap pengunjung dan penduduk dari perdagangan obatobatan terlarang;

d. Perlindungan terhadap tempat tempat kunjungan wisatawan dan fasilitas dari gangguan yang melanggar hukum; e. Panduan bagi operator tempat kunjungan apabila terjadi gangguan;

f. Manajemen kepada media;

g. Informasi yang disediakan bagi perdagangan internasional terhadap isu keamanan dan keselamatan;

h. Manajemen krisis;

i. Standar keselamatan dan praktek difasilitas dan lokasi pengunjung termasuk perlindungan terhadap kebakaran, pencurian, sanitasi, dan persyaratan kesehatan;

j. Pengembangan peraturan dan sanksi di lokasi pengunjung;

k. Aspek keamanan dan keselamatan bagian dari pemberian ijin lisensi bagi usaha akomodasi, restoran, usaha taksi, dan pemandu wisata;

1. Dokumentasi dan informasi mengenai keamanan pengunjung, untuk yang melakukan perjalanan keluar maupun yang datang;

m. Kebijakan nasional mengenai kesehatan pengunjung, termasuk sistem pelaporan maupun masalah kesehatan pengunjung;

n. Asuransi pengunjung dan asuransi travel assistance; dan

o. Penelitian statistik terhadap kejahatan pada pelaku perjalanan

Meskipun sudah terdapat jaminan keselamatan pengunjung namun pemerintah belum mengatur secara detail tentang jaminan tersebut dalam sebuah ketentuan sebagai pelaksana undang-undang yaitu Peraturan Pemerintah. Apabila kebijakan yang tertuang dalam peraturan maka akan mengikat semua pihak termasuk di dalamnya ialah pelaku usaha, pengunjung dan pihak lain, sehingga semua stakeholder mentaati semua aturan main dalam mekanisme yang sudah berlaku. Pengaturan itu menjadi penting mengingat semakin 
beragamnya obyek wisata yang memiliki risiko yang berbeda-beda yang dapat dikategorikan rendah, sedang, tinggi, dan ekstrim. Dalam peraturan tersebut harus secara transparan menjelaskan hal-hal penting terkait dengan jaminan keselamatan pengunjung yang meliputi hak dan kewajiban pengelola wisata, hak dan kewajiban pengunjung, serta hak dan kewajiban pemerintah beserta organisasi independen. Walaupun mendapatkan jaminan, pengunjung tempat wisata tidak dapat semenamena melanggar ketentuan yang berlaku, dan wajib mentaati semua petunjuk dan aturan main, melaksanakan kewajiban seperti membeli karcis tanda masuk, dan batas usia yang diperkenankan mengikuti aktivitas tertentu (Yudhistira dan Susanto, 2012: 21-22).

\section{b. Pengertian Keamanan dan Keselamatan}

Keamanan berasal dari kata dasar aman yang artinya bebas dari bahaya, aman juga berarti bebas dari gangguan. (Kamus Besar Bahasa Indonesia, 2012: 46). Sedangkan Keselamatan berasal dari kata selamat yang artinya adalah terbebas dari bahaya, malapetaka ataupun bencana, atau juga dapat diartikan tidak adanya gangguan dari pihak manapun. (Kamus Besar Bahasa Indonesia, 2012: 1248).

Dari uraian di atas dapat dimaknai bahwa keamanan yaitu sebuah keadaan aman atau ketenteraman seseorang atau sekelompok orang terhadap resiko bahaya yang timbul karena faktor lingkungan .Sedangkan keselamatan adalah perihal keadaan selamat atau keadaan seseorang atau sekelompok orang untuk mendapatkan kesejahteraan dan kebahagiaan. Dalam sebuah kawasan atau destinasi wisata persoalan keamanan dan keselamatan menjadi tanggung jawab semua masyarakat khusunya pengelola obyek wisata aparat keamanan, maupun para pengunjung atau wisatawan pada umumnya. Keadaan obyek wisata yang tidak aman berarti terjadi berbagai hal yang merugikan keselamatan para wisatawan seperti terjadi pencurian, penjambretan, penodongan, dan tindak kejahatan lain, sehingga para pengunjung menjadi tidak tenteram, dan ketakutan akibatnya obyek wisata atau daerah tujuan wisata menjadi terkucilkan karena tidak pernah dikunjungi wisatawan. Sebagai pengelola obyek wisata hendaknya harus tegas terhadap berbagai tindak kejahatan ataupun tindakan para wisatawan yang mencurigakan dan mengarah pada tindakan kejahatan.

Salah satu aspek dari perilaku konsumen (pengunjung) obyek wisata yang berkaitan dengan keputusan untuk membeli produk pariwisata adalah faktor resiko dari produk itu sendiri. Dapat dipastikan bahwa wisatawan akan batal membeli produk wisata, jika konsumen sudah berasumsi bahwa keselamatan dan keamanannya tidak terjamin. Oleh sebab itu, pengelolaan terhadap keselamatan dan keamanan pengunjung sangat diperlukan untuk men-ciptakan kepercayaan kepada pengunjung atas keselamatan dirinya.

\section{Prinsip-Prinsip Dasar Pengelolaan Pariwisata}

Seorang manajer (pengelola) hendaknya dapat mengelola tiga hal yaitu input, proses dan output dari sebuah organisasi, namun demikian manajer tidak dapat mengontrol faktor-faktor yang terjadi di luar organisasi sekalipun faktor-faktor itu juga sangat menentukan keberhasilan seorang manajer. Misalnya keadaan cuaca, musim, bencana alam dan sebagainya. Ada berbagai faktor di luar manajemen yang tidak bisa dikontrol. Oleh karena itu dalam 
rangka menjaga keselamatan dan keamanan para pengunjung sebuah destinasi wisata dalam rangka meningkatkan citra maka pengelola harus memilki berbagai prinsip agar dapat menanggulangi resiko yang dihadapi oleh pengunjung.

Menurut Cox dalam I Gde Pitana dan

I Ketut Surya Diarta (2009: 81), pengelolaan pariwisata hendaknya memperhatikan berbagai prinsip-prinsip sebagai berikut:

a. Pembangunan dan pengembangan pariwisata didasarkan pada kearifan lokal dan special local sense yang merefleksikan keunikan peninggalan budaya dan keunikan lingkungan.

b. Preservasi, proteksi, dan peningkatan kualitas sumber daya yang menjadi basis pengembangan kawasan pariwisata.

c. Pengembangan atraksi wisata tambahan yang mengakar pada khasanah budaya lokal.

d. Pelayanan kepada wisatawan yang berbasis keunikan budaya dan lingkungan local.

e. Memberikan dukungan dan legitimasi pada pembangunan dan pengembangan pariwisata, jika terbukti memberikan manfaat positif, tetapi sebaliknya mengendalikan dan/atau menghentikan aktivitas pariwisata tersebut, jika melampaui ambang batas (carrying capacity) lingkungan alam atau aksesibilitas social, walaupun disisi lain mampu meningkatkan pendapatan masyarakat.

Dewasa ini tantangan pengelolaan pariwisata adalah bagaimana menciptakan keseimbangan keberadaan manusia ketika berada di destinasi wisata dengan lingkungan atau obyek wisata yang ada di destinasi wisata itu sendiri. Kampanye konservasi lingkungan kepada setiap pengunjung di sebuah destinasi wisata hendaknya terus dikampanyekan demi keselamatan dan keamanan pengunjung itu sendiri. Terlebih ketika obyek wisata dalam sebuah destinasi wisata bersifat aktif maka pengelolaan haruslah diarahkan kepada keselamatan dan keamanan pengunjung.

Atas dasar uraian di atas maka untuk menjamin keamanan dan keselamatan pengunjung hendaknya pengelola pariwisata selalu memberikan petunjuk (guidelines) kepada setiap pengunjung melalui berbagai media informasi dan sarana komunikasi, memperbarui dan mengadakan perbaikan berbagai sarana atau atraksi wisata yang disediakan untuk pengunjung, termasuk di dalamnya melakukan perawatan terhadap obyek wisata yang berwujud benda hidup agar terhindar dari penyakit menular (virus) maupun upaya penjinakan jika obyeknya berupa binatang buas yang membayakan keselamatan.

Dalam pasal 2 UU No. 10 Tahun 2009 tentang Kepariwisataan menyebutkan bahwa dalam pengelolaan pariwisata sebagai sebuah bisnis, maka setiap usaha yang dilakukan harus mampu menerapkan asas manfaat, kekeluargaan, adil dan merata, keseimbangan, kemandirian, kelestarian, partisipatif, berkelanjutan, demokratis, kesetaraan dan kesatuan.

\section{Rumusan Hipotesis}

Ho: Tidak terdapat pengaruh yang signifikan antara aspek pengelolaan keamanan dan keselamatan pengunjung dengan citra sebuah destinasi wisata.

\section{METODE PENELITIAN}

Penelitian yang berkaitan dengan Pengelolaan Keamanan dan Keselamatan Pengunjung Terhadap Citra Destinasi 
Wisata ini tergolong jenis riset studi kasus. Penelitian studi kasus dan lapangan (Case and Field Study) yaitu penelitian yang karakteristik masalahnya berkaitan dengan latar belakang dan kondisi saat ini dari subyek yang diteliti. Tujuan penelitian jenis ini melakukan penelitian secara mendalam atau memberikan ulasan obyek tertentu. Jenis penelitian yang berkaitan dengan keamanan dan keselamatan pengunjung ini bersifat deskriptif (Descriptive Reseacrh).

\section{Lokasi Penelitian}

Ide awal pembangunan Kebun Raya dan Kebun Binatang Gembira Loka berasal dari keingian Sri Sultan Hamengku Buwono VIII pada tahun 1933 akan sebuah tempat hiburan, yang dinamakan Kebun Rojo. Ide tersebut direlalisasi oleh Sri Sultan Hamengku Buwono IX dengan bantuan Ir Karsten, seorang arsitek berkebangsaan Belanda. Ir Karsten kemudian memilih lokasi di sebelah barat sungai Winongo, karena dianggap sebagai tempat paling ideal untuk pembangunan Kebun Rojo tersebut. Namun akibat dampak Perang Dunia ke II dan juga pendudukan oleh Jepang, pembangunan Kebun Rojo berhenti. Selang beberapa tahun kemudian, tepatnya tahun 1959, KGPAA Paku Alam VIII menunjuk Tirtowinoto untuk melanjutkan pembangunan Gembira Loka. Dipilihnya Tirtowinoto karena yang bersangkutan dinilai memiliki kecintaan terhadap alam dan minat yang besar terhadap perkembangan Gembira Loka. Ternyata sumbangsih Tirtowinoto yang tidak sedikit, baik dalam hal pemikiran maupun material, terbukti mampu membawa kemajuan yang pesat bagi Gembira Loka. Sehingga pada tahun 1978, ketika koleksi satwa yang dimiliki semakin lengkap, sehingga pengunjung
Gembira Loka mampu mencapai 1,5 juta orang.

Sejak berlakunya Undang-undang (UU) Nomor 16 Tahun 2001 tentang Yayasan dan UU Nomor 28 Tahun 2004 tentang perubahan atas UU Nomor 16 Tahun 2001, maka badan hukum berbentuk yayasan dianggap tidak luwes lagi untuk mengelola suatu usaha, termasuk di dalamnya dalam mengelola dan upaya pengembangan Kebun Raya dan Kebun Binatang KRKB) Gembira Loka. Atas saran Dewan Pembina, dalam hal ini Ngarsa Dalem Sri Sultan Hamengku Buwono X dan Sri Padukan KPAA Paku Alam IX. Maka selanjutnya pada 18 Maret 2008 dibentuklah PT, yang dibidani YGL dinamai PT Buana Alam Tirta (BAT). Kemudian pada 16 November 2009, YGL menjalani kerjasama dengan PT BAT untuk mengelola KRKB Gembira Loka. Dalam kerjasama itu PT BAT ditunjuk dan dipercaya menjadi mitra YGL untuk mengelola KRKB Gembira Loka, yang kemudian lebih dikenal dengan sebutan Gembira Loka Zoo atau disingkat GL Zoo. Perjanjian kerjasama antara YGL dengan PT BAT ini berlaku untuk jangka waktu selama 20 tahun, hingga 16 November 2029.

GL Zoo sendiri mempunyai visi melestarikan tumbuh-tumbuhan dan satwa sesuai dalam habitatnya, sehingga bermanfaat bagi alam dan kehidupan manusia. Sedangkan misinya, mengembangbiakkan dan melestarikan tumbuhan, mensejahterakan satwa dan memelihara (merawat) sesuai habitatnya menangkarkan satwa dengan menjaga kemurnian genetic. Selain itu, juga sebagai pusat penelitian satwa, mmberikan informasi dan sarana pendidikan tentang satwa serta penyadaran untuk mencintai dan melestrikannya. Dengan misi tersebut diharapkan GL Zoo 
tidak hanya menjadi tempat rekreasi berwawasan lingkungan yang kreatif, menarik, dan edukatif. Akan tetapi juga sebagai paru-paru kota dan sebagai cadangan resapan air di Kota Yogyakarta.

Seperti diketahui, sejak pengelolaan PT BAT, pengunjung GL Zoo mengalami kemajuan pesat, setelah sempat terpuruk akibat gempa bumi 2006 lalu. Pada tahun tersebut KRKB Gembira Loka hanya didatangi 354 ribu pengunjung. Namun pasca gempa, berkat pengembangan dan image yang semakin baik, GL Zoo tidak lagi terkesan kotor, bau, kumuh dan gersang. Sejak dikelolan oleh PT BAT, pengunjung GL Zoo terus meningkat signifikan. Terbukti jumlah pengunjung tahu 2011, angka pengunjung nyaris menembus 1,2 juta orang. Terakhir, pada tahun 2012 jumlah pengunjung meningkat hingga 1,4 juta orang lebih. Gembira Loka Zoo merupakan satu- satunya kebun binatang yang berada di Provinsi Daerah Istimewa Yogyakarta. Gembira Loka Zoo berlokasi di Jl. Kebun Raya No. 2 Yogyakarta 51721. Gembira Loka Zoo menempati area seluas 19.88 ha. Ada banyak fasilitas yang bisa dinikmati oleh para pengunjung Gembira Loka Zoo, antara lain fasilitas objek, fasilitas sarana atraksi interaksi, fasilitas sarana rekreasi, fasilitas pelayanan, dan fasilitas sarana penunjang.

a. Fasilitas Objek

Fasilitas objek yang dapat dinikmati pengunjung adalah berupa melihat koleksi flora dan fauna yang terdapat di area Gembira Loka Zoo. Selain itu, pengunjung juga dapat mengunjungi Reptile and Amphibian Park (taman reptile dan ampibi), dan Bird Park (taman burung).

b. Fasilitas Sarana Atraksi Interaksi

Pengunjung dapat melihat atraksi yang dilakukan oleh beberapa satwa yang terdapat di Gembira Loka Zoo, dan juga biasa melakukan interaksi secara langsung dengan mereka seperti halnya:

1) Gelar Satwa Terampil

Gelar Satwa terampil merupakan pertunjukan Satwa yang ada di Gembira Loka Zoo, satwa yang ditampilkan pada pertunjukan seperti burung Kakak Tua Jambul Kuning, Linsang, Beruang Madu, Burung Kangkareng serta Orang Utan. Bagi pengunjung yang ingin menyaksikan Gelar Satwa Terampil ini sudah tidak dipungut biaya lagi alias gratis. Untuk jadwal pertunjukannya pada hari Minggu/Libur : pada pukul 10.00 sampai dengan 15.00. Pada hari Sabtu pukul 11.00 sampai dengan 14.00, dan pada hari Senin - Jumat: pukul 11.00 dan 13.00

2) Feeding Time

Feeding time merupakan waktu makan bagi para satwa yang terdapat di Gembira Loka Zoo. Pengunjung juga bisa melihat dan ikut memberi makanan secara langsung, sesuai dengan jadwal feeding time yang sudah ada. Setiap hari, feeding time Simpanse dimulai pukul 10.30 WIB, feeding time Arapaima dimulai pukul 11.00 WIB, feeding time Ular dimulai pukul 11.30 WIB, feeding time untuk Pucuk Hitam pukul 10.00 WIB dan 13.00 WIB Setiap hari minggu atau hari libur nasional, feeding time Harimau dimulai pukul 12.00 WIB.

c. Fasilitas Sarana Rekreasi 
Di Gembira Loka Zoo, pengunjung bisa menikmati berbagai macam sarana rekreasi yang dibuka mulai pukul 08.30 - 15.30 WIB, antara lain: Kapal Katamaran, Perahu Kayuh, Banana Orea,Perahu Boat, Sepeda Air, Perahu Senggol, Sekuter Air, Speed Boat, Terapi Ikan, Bumper Boat, Kolam Tangkap, Kolam Sentuh, Onta Tunggang, Gajah Tunggang, Sirkuit ATV dan Taring (transportasi keliling)

d. Fasilitas Pelayanan

Terdapat berbagai macam pelayanan yang diberikan Gembira Loka Zoo kepada pengunjung, guna memberikan kenyamanan dan keamanan selama berwisata. Ada pelayanan penjualan karcis masuk ke Gembira Loka Zoo dan penjulan tiket untuk sarana rekreasi, pelayanan siaran dan informasi, pelayanan pendidikan, juga pelayanan keamanan.

e. Fasilitas Sarana Penunjang

Berbagai sarana penunjang juga terdapat di Gembira Loka Zoo, seperti tempat ibadah (mushola) yang terletak di area kebun raya dengan konsep menyatu dengan alam dan berada di tengah rerimbunan pepohonan. Lokasi tepat sebelum tangga turun menuju area kebun binatang. Ada juga mayang tirta, ruang pertemuan, toilet, food court, gerai souvenir, tempat sampah, area parkir dan free wifi zone.

\section{Populasi dan Sampel Penelitian}

Menurut Sugiyono (2013: 119), populasi adalah wilayah generalisasi yang terdiri atas: Obyek atau subyek yang mempunyai kualitas dan karakteristik tertentu yang ditetapkan oleh peneliti untuk dipelajari kemudian ditarik kesimpulannya.
Sampel adalah bagian dari jumlah dan karakteristik yang dimiliki oleh populasi tersebut. Pengambilan sampel dilakukan dengan teknik purposive sampling. Purposive sampling menurut Sugiyono (2013: 46) adalah mengambil responden dengan pertimbangan khusus. Dalam penelitian ini yang dimaksud sampel oleh penulis adalah pengunjung yang berusia dewasa sehingga dapat memberikan jawaban terhadap data yang diperlukan berkaitan dengan pengelolaan keamanan dan keselamatan pengunjung hubungannya dengan citra destinasi kawasan wisata.

Teknik penentuan jumlah sampel penelitian. (Zikmund : 2000 : Business Research Methods, The Dryden Press Harcourt Brace College Publisher, USA:389) memberikan formula tentang penentuan jumlah sampel penelitian sebagai berikut.

$\mathrm{N}=\left[\frac{Z S}{E}\right]^{2}$

Di mana :

$\mathrm{N}$; adalah jumlah sampel;

$\mathrm{Z}$; adalah nilai yang sudah distandardisasi sesuai derajat keyakinan;

$\mathrm{S}$; adalah deviasi standar sampel atau estimasi deviasi standar populasi;

E ; adalah tingkat kesalahan yang ditolelir, plus minus faktor kesalahan (rentangnya antara setengah dari total derajat keyakinan)

Dengan asumsi bahwa derajat kepercayaan 95\% (berarti nilai $\mathrm{z}=1,96$ ) perkiraan deviasi standar 10 (S) dan rentang kesalahan (E) kurang dari 2. Dengan demikian jumlah sampel yang sebaiknya diambil menurut formula diatas adalah : 
$\mathrm{N}=\left[\frac{(1,96)(10)}{2}\right]^{2}=96,04$ (96 wisatawan)

Adapun jumlah sampel diperkiraan sebanyak 100 pengunjung (responden) dengan pertimbangan bahwa sampel dalam penelitian ini lebih bersifat homogen, sehingga sebanyak 100 responden dipandang mewakili.

\section{Variabel penelitian}

Variabel dalam penelitian ini terdiri dari dua (2) bagian, yaitu: variabel bebas (independent variable atau $\mathrm{X}$ ) dan variabel terikat (dependent variable atau $\mathrm{Y}$ ) yaitu citra destinasi wisata. Uraian tentang masing-masing variabel selanjutnya dijelaskan sebagai berikut.

\section{Variabel independen}

Dalam penelitian ini yang dimaksud dengan variabel bebas terdiri dari dua, yaitu: keamanan (sebagai X1) dan keselamatan (sebagai X2). Sedangkan variabel dependen atau variabel terikat adalah variabel yang dipengaruhi atau menjadi akibat karena adanya variabel independen. Dalam penelitian ini variabel dependen yaitu destinasi wisata (sebagai Y).

\section{Teknik pengumpulan data}

Pengumpulan data dalam penelitian ini dilakukan dengan berbagai metode, antara lain sebagai berikut:

\section{Observasi}

Menurut Hadi dalam (Sugiyono, 2013: 196), observasi merupakan suatu proses yang kompleks, suatu proses yang tersusun dari berbagai proses biologis dan psikologis. Dua di antara yang terpenting adalah proses pengamatan dan ingatan. Dalam penelitian ini penulis ingin mendapatkan fenomena yang diinginkan, berkaitan dengan berbagai gambaran umum (deskripsi) tentang Gembira Loka zoo, khusunya berkaitan dengan sejarah, pengelolaan, keorganisasian.

\section{Angket/Kuesioner}

Menurut Sugiyono (2013: 193), kuesioner merupakan teknik pengumpulan data yang dilakukan dengan cara memberi seperangkat pertanyaan atau pernyataan tertulis kepada responden untuk dijawab. Angket dalam penelitian ini menggunakan skala Likert. Skala Likert digunakan untuk mengukur sikap, pendapat dan persepsi seseorang atau sekelompok orang tentang fenomena sosial (Sugiyono, 2013:136). Skala Likert dalam penelitian ini menggunakan 4 skala yaitu :

SS = Sangat Setuju diberi skor 5

$\mathrm{S} \quad=$ Setuju diberi skor 4

$\mathrm{RR}$ = Ragu-Ragu diberi skor 3

KS = Kurang Setuju diberi skor 2

TS = Tidak Setuju diberi skor 1

\section{Dokumentasi}

Menurut Riduwan (2010:58), dokumentasi ditujukan untuk memperoleh data langsung dari tempat penelitian, meliputi: buku-buku yang relevan, peraturan-peraturan, laporan kegiatan, fotofoto, film dokumenter, data yang relevan dengan penelitian. Metode dokumentasi ini di-gunakan untuk melengkapi data yang tidak diperoleh dengan teknik sebelumnya, yaitu dengan mencatat dan atau menyalin bahan-bahan berupa: peraturan-peraturan, panduan-panduan, dan foto-foto destinasi wisata di Gembira Loka zoo.

\section{Metode analisis}

Prosedur analisis data penelitian atau pengujian hipotesis yang telah dikemukakan dalam penelitian ini akan dilakukan melalui berbagai langkah-langkah sebagai berikut. 


\section{Uji Instrumen}

Berdasarkan pada variabel penelitian dan definisi operasional di atas, alat instrumen yang digunakan untuk mengumpulkan data primer dalam penelitian ini adalah angket atau kuesioner yang berupa pertanyaan atau pernyataan tertulis yang diajukan kepada pengujung Gembira Loka Zoo. Adapun alat yang digunakan untuk menentukan opsi jawaban pada kuesioner yaitu menggunakan skala Likert. Uji instrument mencakup: Uji Validitas dan uji reliabilitas.

\section{Analisis Regresi Linier Berganda}

Regresi linier berganda merupakan model yang akan menjelaskan pengaruh variabel independen secara bersama-sama (simultan) terhadap variabel dependen.

\section{Deskripsi Responden Penelitian}

Deskripsi dari 100 responden penelitian sebagai sumber data dideskripsikan melalaui tabel-tabel berikut sebagai berikut.

Tabel 1 : Deskripsi responden berdasarkan umur

\begin{tabular}{|l|l|l|}
\hline \multicolumn{1}{|c|}{ Kategori } & \multicolumn{1}{c|}{ Jumlah } & \multicolumn{1}{c|}{$\%$} \\
\hline$<15$ tahun & 38 & $38 \%$ \\
\hline $15>25$ tahun & 29 & $29 \%$ \\
\hline$<25$ tahun & 33 & $33 \%$ \\
\hline Jumlah & 100 & $100 \%$ \\
\hline
\end{tabular}

Sumber : data primer

Tabel 2 : Deskripsi responden berdasarkan gender

\begin{tabular}{|l|c|c|}
\hline \multicolumn{1}{|c|}{ Gender } & Jumlah & $\%$ \\
\hline Pria & 56 & $56 \%$ \\
\hline Wanita & 44 & $44 \%$ \\
\hline Jumlah & 100 & $100 \%$ \\
\hline
\end{tabular}

Sumber : data primer

Tabel 3 : Deskripsi responden berdasarkan tujuan kunjungan

\begin{tabular}{|l|c|c|}
\hline \multicolumn{1}{|c|}{ Tujuan Kunjungan } & Jumlah & $\%$ \\
\hline Rekreasi & 78 & $78 \%$ \\
\hline Kegiatan pendidikan & 7 & $7 \%$ \\
\hline Keperluan bisnis & 11 & $11 \%$ \\
\hline Keperluan penelitian & 4 & $4 \%$ \\
\hline Jumlah & 100 & $100 \%$ \\
\hline
\end{tabular}

Sumber : data primer

Tabel 4 : Deskripsi responden berdasarkan frekuensi kunjungan

\begin{tabular}{|l|c|c|}
\hline Frekuensi Kunjungani & Jumlah & $\%$ \\
\hline 1 kali & 13 & $13 \%$ \\
\hline 2 kali & 23 & $23 \%$ \\
\hline 3 kali & 64 & $64 \%$ \\
\hline Lebih dari 3 kali & & \\
\hline Jumlah & 100 & $100 \%$ \\
\hline
\end{tabular}

Sumber : data primer 
Tabel 5 : Deskripsi responden berdasarkan daerah asal

\begin{tabular}{|l|l|l|}
\hline Asal & Jumlah & $\%$ \\
\hline DIY & 78 & $78 \%$ \\
\hline Luar DIY & 22 & $22 \%$ \\
\hline Jumlah & 100 & $100 \%$ \\
\hline
\end{tabular}

Sumber : data primer

Berdasarkan tabel-tabel di atas dapat dijelaskan bahwa pengunjung Kebun Binatang Gembira Loka sebagai responden penelitian tertinggi, yaitu: sebanyak 33 orang berumur di atas 25 tahun, berjenis kelamin pria sebanyak 56 orang, dengan tujuan kunjungan adalah rekreasi, rata-rata kun-jungan 3 kali lebih dan tertinggi adalah berasal dari DIY.

\section{Uji Instrumen Penelitian}

a. Uji Validitas Instrumen
Dari hasil uji korelasi Product Moment akan menghasilkan nilai atau harga r. Apabila koefisien korelasi rendah atau $r$ hitung lebih kecil dari $r$ tabel pada taraf signifikansi 5\%, maka butir-butir yang bersangkutan dikatakan gugur atau tidak valid. Perhitungan uji validitas dengan alat bantu SPSS 13.0 dari perhitungan masingmasing variabel penelitian diperoleh hasil nilai validitas sebagai berikut:

Tabel 6 : Variabel x1 (Keamanan Pengunjung)

\begin{tabular}{|c|c|c|c|}
\hline Item Soal & r hitung & r tabel & Keputusan \\
\hline 1 & 0.776 & 0.195 & vallid \\
\hline 2 & 0.819 & 0.195 & vallid \\
\hline 3 & 0.632 & 0.195 & vallid \\
\hline 4 & 0.785 & 0.195 & vallid \\
\hline 5 & 0.746 & 0.195 & vallid \\
\hline
\end{tabular}

Tabel 7 : Variabel x2 (Keselamatan Pengunjung)

\begin{tabular}{|c|c|c|c|}
\hline Item Soal & r hitung & $\mathrm{r}$ tabel & Keputusan \\
\hline 1 & 0.856 & 0.195 & vallid \\
\hline 2 & 0.890 & 0.195 & vallid \\
\hline 3 & 0.859 & 0.195 & vallid \\
\hline 4 & 0.778 & 0.195 & vallid \\
\hline 5 & 0.350 & 0.195 & vallid \\
\hline
\end{tabular}

Tabel 8 : Variabel y (Citra Destinasi)

\begin{tabular}{|l|c|c|c|}
\hline Item Soal & r hitung & r tabel & Keputusan \\
\hline 1 & 0.547 & 0.195 & vallid \\
\hline 2 & 0.767 & 0.195 & vallid \\
\hline 3 & 0.652 & 0.195 & vallid \\
\hline 4 & 0.601 & 0.195 & vallid \\
\hline 5 & 0.376 & 0.195 & vallid \\
\hline 6 & 0.708 & 0.195 & vallid \\
\hline 7 & 0.718 & 0.195 & vallid \\
\hline 8 & 0.620 & 0.195 & vallid \\
\hline
\end{tabular}


Dari tabel diatas menunjukkan bahwa semua butir-butir pernyataan dari masing-masing variabel penelitian dinyatakan valid karena nilai $r$ hitung $>$ r tabel.

b. Uji Reliabilitas

Reliabilitas mengukur apakah tiap item-item dapat dipakai sebagai alat ukur yang konsisten. Pedoman pengujian untuk reliabilitas adalah 0.70
(Suharsimi:2010:246). Jika nilai reliabilitas > 0.70 dinyatakan bahwa item dalam instrumen reliable. Pengujian reliabilitas instrument dalam penelitian ini dilakukan melalui rumus Alpha Cronbach. Dengan pedoman tersebut hasil dari realibilitas masingmasing variabel tersaji dalam tabel berkut :

Tabel 9 : Variabel x1 (keamanan pengunjung)

\begin{tabular}{|c|l|l|c|}
\hline Item & Cronbach's Alpha & Pedoman & keputusan \\
\hline 1 & 0.763 & 0.70 & reliabel \\
\hline 2 & 0.748 & 0.70 & reliabel \\
\hline 3 & 0.814 & 0.70 & reliabel \\
\hline 4 & 0.759 & 0.70 & reliabel \\
\hline 5 & 0.772 & 0.70 & reliabel \\
\hline
\end{tabular}

Tabel 10 : Variabel x2 (keselamatan pengunjung)

\begin{tabular}{|c|l|l|l|}
\hline Item & Cronbach's Alpha & pedoman & keputusan \\
\hline 1 & 0.702 & 0.70 & reliabel \\
\hline 2 & 0.781 & 0.70 & reliabel \\
\hline 3 & 0.704 & 0.70 & reliabel \\
\hline 4 & 0.740 & 0.70 & reliabel \\
\hline 5 & 0.901 & 0.70 & reliabel \\
\hline
\end{tabular}

Tabel 11 : Variabel y (Citra Destinasi)

\begin{tabular}{|l|l|l|l|}
\hline Item & Cronbach's Alpha & pedoman & keputusan \\
\hline 1 & 0.773 & 0.70 & reliabel \\
\hline 2 & 0.717 & 0.70 & reliabel \\
\hline 3 & 0.741 & 0.70 & reliabel \\
\hline 4 & 0.751 & 0.70 & reliabel \\
\hline 5 & 0.791 & 0.70 & reliabel \\
\hline 6 & 0.731 & 0.70 & reliabel \\
\hline 7 & 0.730 & 0.70 & reliabel \\
\hline 8 & 0.748 & 0.70 & reliabel \\
\hline
\end{tabular}

Dari tabel di atas menunjukkan bahwa semua butir-butir pernyataan dari masing-masing variabel peneli- tian dinyatakan reliable karena nilai Cronbach's Alpha $>0.70$.

c. Pengujian Hipotesis Penelitian 
Tabel 12 : Descriptive Statistics

\begin{tabular}{|l|r|r|r|}
\hline & \multicolumn{1}{|c|}{ Mean } & Std. Deviation & \multicolumn{1}{c|}{ N } \\
\hline citra & 31.27 & 3.698 & 100 \\
keamanan & 20.98 & 2.274 & 100 \\
keselamatan & 19.37 & 2.859 & 100 \\
\hline
\end{tabular}

Tabel 13 : Correlations

\begin{tabular}{|ll|r|r|r|}
\hline & & \multicolumn{1}{|c|}{ citra } & keamanan & keselamatan \\
\hline Pearson Correlation & citra & 1.000 & .494 & .752 \\
& keamanan & .494 & 1.000 & .469 \\
& keselamatan & .752 & .469 & 1.000 \\
\hline Sig. (1-tailed) & citra & .000 & .000 \\
& keamanan & .000 &. & .000 \\
& keselamatan & .000 & .000 & \\
\hline $\mathrm{N}$ & citra & 100 & 100 & 100 \\
& keamanan & 100 & 100 & 100 \\
& keselamatan & 100 & 100 & 100 \\
\hline
\end{tabular}

\section{HASIL DAN PEMBAHASAN}

Analisis output bagian pertama dan kedua (Descriptive Statistics dan Correlations)

Rata-rata variabel Citra Destinasi (dengan jumlah data sebanyak 100) adalah 31.27 dengan standar deviasi 3,698

Rata-rata variabel keamanan (dengan jumlah data sebanyak: 100) adalah 20.98 dengan standar deviasi 2,274

Rata-rata variabel keselamatan (dengan jumlah data sebanyak 100) adalah 19,37 dengan standar deviasi 2,859

Angka korelasi antara variabel Citra Destinasi dengan variabel Keamanan Pengunjung adalah sebesar 0.494 (moderat), variabel Citra Destinasi dengan variabel Keselamatan Pengunjung adalah 0,752 (kuat). Secara teoritis dapat diterangkan bahwa korelasi antara variabel Citra Destinasi dengan variabel Keamanan mau- pun variabel Keselamatan Pengunjung berupa korelasi positip yang searah. Peran Variabel Keselamatan Pengujung lebih besar, bila dibandingkan dengan peran variabel Keamaman Pengunjung dalam menentukan penilaian terhadap Citra Destinasi

Antara kedua variabel bebas yaitu variabel Keamanan Pengunjung dan variabel Keselamatan Pengunjung didapatkan angka korelasi sebesar -0,496. Angka ini bersifat sangat moderat artinya tidak terjadi adanya multikolinieritas antara kedua variabel bebas.

Tingkat signifikansi korelasi satu sisi dari output diukur berdasarkan probabilitasnya adalah 0.000 dan 0.000 kedua angka ini berada lebih besar dari 0.05 , oleh karenanya dapat disimpulkan bahwa tidak terdapat hubungan yang signifikan 
Tabel 14 : Model Summary

\begin{tabular}{|l|r|r|r|r|}
\hline Model & R & R Square & $\begin{array}{c}\text { Adjusted R } \\
\text { Square }\end{array}$ & $\begin{array}{c}\text { Std. Error of } \\
\text { the Estimate }\end{array}$ \\
\hline 1 & $.769^{\mathrm{a}}$ & .591 & .583 & 2.389 \\
\hline
\end{tabular}

a. Predictors: (Constant), keselamatan, keamanan

Dependent Variable: citra

Tabel 15. ANOVA ${ }^{b}$

\begin{tabular}{|c|c|c|c|c|c|}
\hline Model & $\begin{array}{l}\text { Sum of } \\
\text { Squares }\end{array}$ & Df & Mean Square & $\mathrm{F}$ & Sig. \\
\hline Regression & 800.249 & 2 & 400.125 & 70.126 & $.000^{\mathrm{a}}$ \\
\hline Residual & 553.461 & 97 & 5.706 & & \\
\hline Total & 1353.710 & 99 & & & \\
\hline
\end{tabular}

a. Predictors: (Constant), keselamatan, keamanan

b. Dependent Variable: citra

Analisis output bagian ketiga dan keempat (Model Summary dan ANOVA)

besarnya angka $\mathrm{R}$ Square adalah 0,583 hal ini berarti bahwa Citra Destinasi dapat dijelaskan oleh variabel Keamanan Pengunjung dan variabel Keselamatan Pengunjung sebesar 58,3\%, sedangkan sisanya sebesar 41,7 dijelaskan oleh faktor lain.

Standard Error of Estimate 2,389 dengan memakai satuan variabel dependen (Citra Destinasi), sedangkan standar deviasi dari variabel Keamanan Pengunjung (pada bagaian satu) adalah sebesar 2,274) dan variabel Keselamatan Pengunjung lebih besar dari standar error of estimate, maka dikatakan bahwa model regresi lebih bagus bertindak sebagai prediktor Citra Destinasi dari pada rata-rata Citra Destinasi itu sendiri.

Dari uji Anova besarnya nilai $\mathrm{F}$ test hitung adalah 70,126 dengan tingkat signifikansi berdasarkan probabilitas adalah 0.000 angka ini lebih kecil dari 0.05 maka secara statistik dapat dinyatakan bahwa model regresi ini dapat dipakai untuk memprediksi Citra Destinasi. Atau secara bersama sama (simultan) bahwa variabel Keamanan Pengunjung dan variabel Keselamatan Pengunjung berpengaruh terhadap Citra Destinasi.

Tabel 16 : Coefficientsa

\begin{tabular}{|l|l|r|r|r|r|r|}
\hline \multirow{2}{*}{ Model } & \multicolumn{2}{|c|}{ Unstandardized Coefficients } & $\begin{array}{l}\text { Standardized } \\
\text { Coefficients }\end{array}$ & \multirow{2}{*}{ T } & \multirow{2}{*}{ Sig. } \\
\cline { 3 - 5 } & B & Std. Error & \multicolumn{1}{c|}{ Beta } & & \\
\hline \multirow{3}{*}{1} & Constant $)$ & 8.366 & 2.325 & & 3.598 & .001 \\
\cline { 2 - 7 } & keamanan & .296 & .120 & .182 & 2.474 & .015 \\
\cline { 2 - 5 } & Keselamatan & .862 & .095 & .667 & 9.070 & .000 \\
\hline
\end{tabular}

a. Dependent Variable: citra 
Analisis output bagian kelima

(Coefficients $(a)$ )

Persamaan garis regresi

$\mathrm{Y}=8,366+0.296 \mathrm{X} 1+0.862 \mathrm{X} 2$

\section{Dimana :}

$\mathrm{Y} \quad=$ Citra Destinasi

$\mathrm{X} 1=$ Keamanan Pengunjung

$\mathrm{X} 2$ = Keselamatan Pengunjung

konstanta sebesar 8,366 berarti bahwa tanpa adanya pengaruh dari Keamanan dan Keselamatan maka besarnya Citra Destinasi adalah 8,366

koefisien regresi X1 adalah 0.296 menyatakan bahwa setiap penambahan 0,296 satuan Keamanan Pengunjung akan berakibat pada penambahan satu satuan pada Citra Destinasi.

Koefisien regresi X2 adalah 0,862 menyatakan bahwa setiap penambahan sebesar 0,862 satuan Keselamatan Pengunjung akan mengakibatkan meningkatnya tingkat Citra Destinasi sebesar satu satuan

\section{KESIMPULAN}

Berdasarkan hipotesis yang telah dikemukakan di bagian terdahulu, maka dapat dilakukan pengambilan kesimpulan sebagai berikut.

1. Berdasarkan $\mathrm{t}$ hitung yaitu bahwa Statistik t hitung 3,598 sedangkan besarnya statistik $\mathrm{t}$ tabel pada signifikansi $(\alpha) 5 \%$ dengan df (degree of freedom) sebanyak $\mathrm{n}-2(100-2)=$ 98 uji dilakukan dua sisi besarnya adalah 1.658. Oleh karena Statistik Hitung > dari statiktik Tabel maka Ho ditolak

2. Berdasarkan probabilitas, terlihat bahwa pada kolom sig/Significance adalah 0.001 atau probabilitas < dari 0.05, maka Ho ditolak

3. Keputusan yang dapat diambil yaitu menerima Ha berarti koefisien regresi signifikan atau Citra Destinasi benarbenar dipengaruhi secara signifikan oleh Keamanan dan Keselamatan pengunjung.

\section{DAFTAR PUSTAKA}

Danang Sunyoto. 2011. Analisis Regresi dan Uji Hipotesis. Yogyakarta: Caps

Departemen Pendidikan Nasional. 2012. Kamus Besar Bahasa Indonesia. Edisi keempat Pusat Bahasa. Jakarta: Gramedia Pustaka Utama.

Doone Robertson, Ian Kean, dan Stewart Moore. 2006. Manajemen Resiko Pariwisata: Pedoman Resmi Menanggulangi Krisis Pariwisata, Singapura: APEC. http://www. crctourism.com.au/wms/upload/ resources/aicst/06_twg_riskmgmt_G uide\%20indo.pdf, diakses 14 Februari 2015.

Frans Gromang. 2002. Tuntunan Keselamatan dan Keamanan Wisatawan. Jakarta: Pradnya Paramita.

I Gde Pitana dan I Ketut Surya Diarta. 2009. Pengantar Ilmu Pariwisata. Yogyakarta: Andi Yogyakarta.

International Labour Organization. 2013. Keselamatan dan Kesehatan Kerja, Sarana untuk Produktivitas. Jakarta: ILO.

KANWIL DEPARPOSTEL DIY. 1990. Panduan Sapta Pesona. Yogyakarta: Deparpostel.

Malayu, Hasibuan. 2014. Manajemen Sumberdaya Manusia. Edisi Revisi. Jakarta: Bumi Aksara.

Muljadi A.J. 2009. Kepariwisataan dan Perjalanan. Jakarta: PT Raja Grafindo Persada. 
Nyoman S Pendit. 1994. Ilmu Pariwisata :

Sebuah Pengantar Perdana. Jakarta.

PT.Pradnya Paramita

Permenaker No. 05/MEN/1996 tentang

Sistem Manajemen Keselamatan dan Kesehatan Kerja

Philip Kotler. 2002. Pemasaran Industri Jasa. Jakarta: UI Press

Subekhi dan Mohammad Jauhar. 2012. Pengantar Manajemen Sumber Daya Manusia (MSDM). Jakarta: Prestasi Pustaka

Sudjana. 1996. Metode Statistik. Bandung: Tarsito

Sugiyono. 2013. Metode Penelitian Kombinasi (Mix Methods). Bandung: Alfabeta

Suharsimi Arikunto. 1992. Prosedur Penelitian. Jakarta: Rineka Cipta.

Sutrisno, E. 2009. Manajemen Sumber Daya Manusia. Jakarta: Prenada Media Gorup.

Undang-Undang Nomor 13 Tahun 2003 tentang Ketenagakerjaan

Undang-Undang Nomor 10 Tahun 2009 tentang Kepariwisataan 